\title{
RENTIER ECONOMY OF THE KURDISH REGION IN IRAQ AS A SOURCE OF BARRIERS FOR THE REGIONAL SECURITY SECTOR REFORM
}

\author{
Piotr SOSNOWSKI, MA \\ p.sosnowski044@gmail.com \\ University of Warsaw, Poland
}

\begin{abstract}
Despite the uncertainty about the Peshmerga's status, western countries besides training and arming the Iraqi Kurds are working with them to reform Peshmerga forces. The aim of this article is to identify and explain some of the barriers for the Regional Security Sector Reform which comes from oil dependence. The author assumed that explaining the historical context of some of the barriers emerging could be helpful during the reform planning process.
\end{abstract}

Keywords: Rentier State, Kurdistan Region, de facto state, Security Sector Reform, Iraq

\section{Introduction $^{1}$}

Since 2014, Western public opinion has seen Iraqi Kurdistan mostly through the lens of the struggle with so called Islamic State (Daesh) and enormous humanitarian

1 I would like to thank Brig. Gen. Hazhar Omer Ismail, Director of Coordination and Relations for the Ministry of Peshmerga Affairs whose contribution to this work was of great significance and dr Renata Kurpiewska-Korbut for comments that greatly improved the manuscript. 
crisis. Kurdish security forces known as Peshmerga ${ }^{2}$ are receiving support from the anti-terrorist coalition, not only because of its role in the fight against Daesh. Just after the fall of the Saddam Hussein regime in 2003, the US Army ${ }^{3}$ has started its efforts to reform and unify the Peshmerga who were controlled by two rivalry political parties - the Patriotic Union of Kurdistan (PUK) and the Kurdistan Democratic Party (KDP). Some of the units of Peshmerga are under the control of the Ministry of Peshmerga Affairs ${ }^{4}$ (MoPA) but the units $70^{\prime}$ and $80^{\prime 5}$ are in the full control of political parties. Today combining all of the Peshmerga forces under the MoPA's control seems to be the greatest challenge for the Regional Security Sector Reform (RSSR) .

2 Peshmerga, Pêşmerge, literally Before death, or Those who face death. The Iraqi authorities are in no doubt that Peshmerga is a part of the Iraqi Army, but in fact, neither the Iraqi Ministry of Defence, nor the Ministry of Interior have any control over Kurdish troops.

3 Despite the uncertainty about the Peshmerga's status, western countries do not only train and arm Iraqi Kurds, multi-national advisors from Germany, U.K. and U.S. are working with Iraqi Kurds to reform Peshmerga forces.

4 The Ministry of Peshmerga was formally established on April 2009 following the 2006 unification agreement between the KDP and PUK and a series of Peshmerga laws passed by the Kurdistan National Assembly in 2007. The ministry should merge units 70' and 80' which are controlled by KDP and PUK into the Kurdistan Regional Guards. That is pursuant to Article 121, Section 5 of the October 2005 Constitution of Iraq.

5 Forces until direct control of the Political Bureaus. Each one counts (officially) 60000 in manpower.

6 Probably the first accessible publication on the reform of the KRG Security Sector Reform (SSR) is "Security Forces of the Kurdistan Regional Government” by Dennis P. Chapman. This book describes in detail both the structure of the Regional Security Sector and some of determinants of reforms. However, it does not define the term SSR even though it refers to it exactly. In line with the OECD-DAC's SSR guidelines, a national security sector is seen as including the law enforcement institutions (police, gendarmerie, customs, border guards, etc.), the criminal justice system (i.e. penal courts, prosecutor's office, corrections), the armed forces, the intelligence services, the institutions that provide political, financial and judicial oversight (line ministries, parliamentary committees, court of auditors, the judiciary, etc.) and non-state security actors, including customary authorities, traditional courts, guerrillas and liberation armies, private military and security companies. See: The OECD DAC Handbook on Security System Reform: Supporting Security and Justice (OECD Publishing, Paris) and Elements for an EU-wide strategic framework to support security sector reform JOIN/2016/0031, Strasbourg 2006. In the following paper, I use the form Regional Security Sector Reform to emphasise that the reform concerns the federal region. The RSSR is the process of transforming a regional security system so that it gradually provides individuals and the region with more effective and accountable security in a manner consistent with respect for human rights, democracy, the rule of law and the principles of good governance. SSR is a long-term and political process, as it goes to the heart of power relations inside the KRG and simultaneously between the KRG and the Iraqi Central Government. 
According to article 117 of the Iraqi Constitution, regions are allowed to establish their own security services. Therefore, the Peshmerga should not be recognised merely as a regional security force but as a separate Kurdish defence system. The internal sovereignty of the Kurdish Regional Government, its legal system, and security forces suggest that the Iraqi Kurds often seem to act as an independent state. The Peshmerga, in particular, operates entirely independently of the Iraqi government, e.g. it has deployed its forces not only in areas disputed with Iraq but also abroad - from Turkey to territories controlled by Syrian Kurds. Peshmerga forces are supplied (in some cases directly, without Central Government permission) by Western governments, e.g. U.S., France, United Kingdom, Canada, Germany, Italy and Holland (Smith 2018). Nevertheless, in line with international humanitarian law, Peshmerga is an integral part of the Iraqi Army (Smith 2018).

The state-centric orientation of the security sector reform could be unsatisfactory (e.g. Afghanistan, Timor-Leste, Libya, Sudan) for two reasons. Firstly, it carries out models that do not correspond to local interests. Secondly, it attempts to rapidly change a local community (Paris 2004; Barnett and Zürcher 2009). As each entity defines security in response to its own national goals (Sedra 2010 p. 18), this paper intends to provide a political and historical context of the obstacles for the reforms.

The aim of the article is to find and explain some of the barriers for the RSSR which comes from oil dependence. The rentierism of the Kurdish economy is associated with existing specific formal and nonformal rules. Those rules are abridging activity of social relation actors in the Region and as a consequence pose challenge for the RSSR.

The barriers for the RSSR have their sources in the KRG dependence on oil revenues, which gives not only that region but the whole of Iraq special circumstances and risks. Iraqi Kurdistan is a region of Federal Iraq which, in general, is deregulated, militarised and organised along sectarian lines and is a hydrocarbons rent seeker.

Publications on the Kurdistan Region's Security Sector usually do not address the barriers that impede introducing the reforms of the Iraqi Kurdistan's Security Sector. If these obstacles are mentioned, they are described briefly and their origins 
and context are not explained (Fliervoet 2018 p. 20). Economic issues are omitted and usually presented from the apparent perspective shaped by the policy of the countries involved in the region?

\section{Rentier economy}

The rentier type of economy derives a dominant fraction of its fiscal revenue from external rent, typically in the form of profit taxes or production sharing agreements with foreign hydrocarbons extracting companies and consequently, is alleviated from the need to tax citizens (e.g., Beblawi and Luciani 1987; Karl 1997). Due to the relatively undiversified nature of the Iraqi economy, the whole country (including Kurdistan Region) depends on imports. There is a significant difference between the demand and the local production of tradable goods in the Kurdistan Region. Hydrocarbons exports account for around 95\% of Iraq's total export basket (World Bank 2015). On the other hand, imports account for around $90 \%$ of non-oil-related GDP. Local production is limited to retail trade of imported products, small goods and other services. The export of locally produced goods is very limited. This is a typical feature of the rentier economy. The situation is aggravated by the lack of customs policy that could support local entrepreneurs in competing with imports. Without the development of the private sector, it will not be possible to diversify sources of budget revenues and to achieve acceptable level of economic security.

The key problem is the instability of public spending, which comes from the fluctuation of the KRG income. Its size is primarily influenced by the price of hydrocarbons on global markets. Additional factors that contribute to these difficulties include interruptions in the production and transport of raw materials as a result of conflict or technical sabotage and the course of the dispute with the Iraqi Central Government about the distribution of revenues from hydrocarbon exports. The budgetary contribution of the private sector is of minor importance.

7 Economically, Iraqi Kurds sit on a sea of oil, which can help to fuel their economy and the economies of neighbours such as Turkey and Syria. (...) This combination of location, economic potential, and proAmerican sentiment make the Iraqi Kurds an ideal ally. (Helfont 2017 p. 6) 
It is being largely replaced by the public sector and, to a lesser extent, by many foreign humanitarian organisations. Sustainability of the public sector is necessary to deal with uncertain and volatile transfers of income and to support economic diversification carried out by the private sector. There are many barriers to achieving that outcome - some of them are shared with RSSR, e.g. corruption, nepotism, lack of political will. All of them are typical for rentier states. It is necessary firstly to explain the historical dependences which pushed the emerging Kurdish economy into the path of rentierism. It could provide a context which may be helpful during the reform planning process.

Some scholars (Ross 2012; Noori 2016; Heshmati and Auzer 2018) have already pointed out that the KRG face so called resource curse. Moreover, it is reasonable to believe that discovering natural resources was a reason that led to restrained Kurdish self-determination efforts after the collapse of the Ottoman Empire (Mills 2016, p. 2) .

\section{Historical sources for the emergence of rentierism in the Kurdistan Region in Iraq}

Firstly, it is necessary to explore the historical origins of the barriers blocking RSSR. The author presumes that some of them developed as a consequence of certain decisions of the international community toward Iraqi Kurds ${ }^{9}$. The regional order in post-Ottoman areas after World War I emerged with countries controlling large areas where local legitimacy of their power was lacking. That determined the future indifference of the Kurdish community and instrumentalisation of the Kurdish issue. None of the efforts for creation of local institutions by the Kurds were legitimised during that period. This is among the reasons why the young Kurdish administration is currently trying to develop and adapt the relevant institutional rules. In combination with negative rentierism-related effects

8 Tractate of Sevres gave Kurds autonomy and allowed Kurds to declare the Kingdom of Kurdistan. Discovery of the oil may have convinced Great Britain to suppress the emerging Kurdish state by the Sevres pact in 1924

9 The author's approach is inspired by the path dependence concept. (David 2007; North 1994) 
(e.g. corruption, clientelism, nepotism, lack of structural development) and the unstable neighbourhood, the RSSR is at an enormous disadvantage.

Nowadays, the institutions of the Kurdistan Regional government must learn everything from scratch. The Iraqi institutions which were functioning in Iraqi Kurdistan were more instruments of Arabisation and a systematic oppression than civil administration. Before 2003, the Kurdistan Region experienced highly unfavourable conditions for the development of the economy. There was neither an effective banking or insurance system nor infrastructure such as power plants, highways, water treatment plants, agriculture and heavy industry, airports, etc. Kurdish authorities lacked adequate data about the state of the economy and population as there was no information gathering and management organisation (Jafar 2006, p. 130).

Lack of development was the intended result of the Baathist party policy, which generally limited investments in North Iraq to the tourism sector designed for party leadership and the family of Saddam Hussein ${ }^{10}$. The Iraqi government pursued a policy of Arabisation, resettlement, ethnic cleansing and genocide during this period (e.g. the operation of al-Anfal ${ }^{11}$ ). The destructive influence of the Iran-Iraq War (1980-1988) must also be mentioned in this context.

The Provide Comfort ${ }^{12}$ operation and the creation of a safe haven enabled international organisations to enter Iraq. The international community has taken over many functions of the state in vast areas of Iraq, and especially in Iraqi Kurdistan. As a result of the protection from the international community,

10 Period of peace and political stabilization before Kurdish revolt in 1961 and the mid1970s can be considered as exception of the long standing conflict with Iraq. In terms of construction projects, the period 1970-4 was described as a 'golden era' for the Kurds, particularly as the governors were also members of the KDP and the influence of the Government of Iraq was minimal (Stansfield 2003, pp. 42-44 ).

11 That name includes eight military campaigns carried out by the Iraqi army between 23 February and 6 September 1988 in the northern part of Iraq, inhabited exclusively or predominantly by the Kurdish population.

12 In 1991, an uprising broke out against Saddam Hussein in the north and south of Iraq. Fearing a massacre, the population began to massively migrate towards the border with Turkey. On April 5, the UN Security Council adopted resolution 688 condemning the repression of Iraqi authorities against civilians and demanded the release of international humanitarian organisations into Iraq. A day later, the Provide Comfort operation began, in which the United States, the United Kingdom and France established a no-fly zone north of the 36th parallel. 
the Iraqi Kurds could form a regional government (in theory it functioned from $1974^{13}$, in practice most positions were held by Arab officials of the Baathist party). The involvement of the international community during the Food for Oil programme made it possible for the Iraqi Kurds to survive. Opening the region to the world has enabled the movement of people, ideas, resources, development and survival of its inhabitants. Food was delivered to over $60 \%$ of the Iraqi population, significantly reducing hunger. $65 \%$ of villages destroyed by the Iraqi army during the An-Anfal were rebuilt ${ }^{14}$. Despite that, the development of Iraqi Kurdistan was unintentional. The main aim of the international organisations was to stop refugees who were migrating towards the border with Turkey.

UN agencies and humanitarian organisations providing assistance in Iraqi Kurdistan ignored democratic institutions emerging from the first regional parliamentary elections in 1992. Distribution of aid was organised in cooperation with local tribal leaders instead of the newly elected government (Leezenberg 2000). International organisations avoided legitimising the Kurdish regional power, even though it was legal in local and international law. It caused the strengthening and freezing of local structures based on tribes and clans. As a result, the institution of Wasta $^{15}$, clientelism and other negative phenomena were enhanced by the presence of the international community alleviation. This strengthened rivalry between political parties and could have been one of the causes of the civil war between the KDP and PUK in 1994.

The absence of consent from the international community for any type of selfdetermination (including autonomy) could have conditioned the young Kurdish economy to the rentier's role. It resulted not only in the economic and political

131974 Autonomy Law which was to be introduced according to the 1970 March Manifesto.

14 During Al-Anfal operation, 100,000 to 200,000 civilians died, 4,000 villages and more than 20 cities were destroyed. 1754 schools, 270 hospitals, 2450 mosques and 27 churches were demolished. One and a half million people had to leave their homes as a result of resettlement and to escape from the Iraqi security apparatus (Kamiński 2016 p. 6-9).

15 is a form of nepotism associated with family and tribe members and quite common in MENA (Middle East and North Africa region). In its simplest form, it means using a common connection in order to receive undue benefits. While it is used to cut through lines in government agencies, or speed up an administrative process, its most common use is for entry into the job market, namely in the public administration. Charles D. Adwan "Corruption Terminology in the Arabic Language" (pamphlet), available at http://siteresources.worldbank.org/ INTMNAREGTOPGOVERNANCE/Resources/CharlespieceonTerminology.pdf. 
isolation of the region, but also numerous conflicts and genocides. The way the Oil for Food programme was implemented made the Region dependent on external influences and devastated agriculture, which steered its economy to the rentier's path. It is estimated that $70 \%$ of the professionally active Kurdish population has become dependent on humanitarian aid (Katzman and Blanchard 2009, p. 13). The local market was flooded with cheap foreign food products. This led to the destruction of local agriculture production and resulted in dependence on the import of almost all goods.

UNagencies were under strong pressure from the Saddam regime, which suspended economic and infrastructural projects that could have brought long-term benefits to the Kurdish population (Leezenberg 2000). Iraq effectively corrupted UN employees and partners. It was shown that about 270 companies and individuals were involved in the illegal trade in Iraqi oil (Katzman and Blanchard 2009, p. 13). Projects of demining, rebuilding agriculture, reconstruction of electricity network or power plants were rejected as "too developmental" (Kurpiewska-Korbut 2014, p. 150). Projects implemented in the 90s did not include mechanisms to stimulate long-term planning and development. The Iraqi authorities were not the only ones satisfied with the ineffectiveness of the UN. For example, Turkey blocked the use of UN funds to build a banking system in Iraqi Kurdistan (Kurpiewska-Korbut 2014, p.150). None of the Turkish decision makers at the time expected that less than two decades later, Turkish companies would find themselves seeking to open banks in 'Northern Iraq'. To sum up: the relative development of Iraqi Kurdistan at this time can be described as unintended side effect of the involvement of international community.

In such unfavourable conditions, neither infrastructure nor an appropriate organisational culture could have developed. The education system, which was in its essence a tool of Arabisation, could not create effective elites. Conditions for development of entrepreneurship which could have neutralised the negative effects of rentierism could not have been created. The foundations for entering a rentier economy emerged during that period and determined the emergence of various kinds of barriers for the RSSR.

Although the mountainous nature of the Kurdish region has protected its inhabitants from foreign invasion for centuries, it has also isolated them from emerging ideas of identity and state. It has also nurtured forceful tribal rivalries 
so Kurdish parties have often sided with a common enemy (Turkey, Iran, Iraq) to undermine each other. However, after the internal war between the PUK and KDP (1994-1998), and the fall of the Baathist regime in 2003, saw conflicts put aside and motivated both parties to form a unified regional government to represent Kurdish interests in the new Iraq. The Regional Government divided power between two parties.

\section{Barriers for regional security sector reform emerged from the rentier economy in the Kurdistan Region in Iraq}

The Iraqi Kurds aspirations were partially addressed when the suitable strategic interest of the United States appeared in 2003. The consequence was the implementation of international aid programmes, recognition of the Regional Government and federalisation of Iraq by the 2005 Iraqi Constitution. Dynamic development of the Region strengthened by high oil prices and high level of security attracted foreign investments. It resulted in the "flooding" of the fledgling administration with a large amount of money. A relatively large number of people involved in the political and armed struggle were almost immediately rewarded for their attitude (including their families) in the easiest way - positions in the regional administration (including security structures). It was not possible to offer another form of gratification because of lack of acquaintance with local structures. The Iraqi Kurds focused on the struggle for survival, at the same time being isolated from the rest of the world. Wherefore, they could not come up with proper rules for public administration and planning culture.

Political nepotism in the KRG has a similar character to the one which occurred in the Second Republic of Poland, especially after the May Coup. State positions were filled with veterans of the independence struggle which constituted an important power base. It was the new social elite that succeeded landowners. Similarly, in the Kurdistan Region, the elite are the old Peshmergas from the societies of two competing PUK and KDP leaders - Jalal Talabani and Masoud Barzani. Both political parties draw their real power in the Kurdistan Region from distributing public positions. Allocations of positions depend on the party affiliation and is a reward for loyalty demonstrated by support in the fight against 
the Saddam regime or in the fratricidal war between the PUK and KDP (19941997). Employment in a public position, especially in the security sector, requires the support of a political party that executes its real power in a given province ${ }^{16}$.

Despite support from Western countries (especially from the US), both parties have not yet reached an agreement on the unification of Peshmerga. This caused a number of negative consequences regarding the image of the KRG, internal instability and the inability to effectively use the armed forces. A recent example is the loss of Kirkuk in October 2017, where PUK Peshmerga withdrew from a strategic position on the outskirts of the city without coordination with the KDP Peshmerga. As a result, there was a serious political crisis inside Iraqi Kurdistan and the loss of about $50 \%$ of the controlled territories (disputed areas) for Iraqi security forces ${ }^{17}$. It is worth adding that the main core of the offensive on the disputed areas was the Hashd Al-Shabi militia, commanded by Iranian military advisers, which adds an additional geopolitical dimension on top of that.

Rentier economies spend a significant portion of their revenues on the security sector in order to protect the source of their income and prevent loss of power. In the case of Iraqi Kurdistan, safety expenditure is compounded by many different factors. The constant feeling of danger is caused by the hostile external environment and internal uncertainty caused by the duality of the political power of the armed parties. The financial income of both of those parties mostly relies on the different external partners: KDP on Turkey and PUK on Iran. Furthermore, both of that external partners are in internal and external conflict with other Kurdish armed parties.

Externally, the armed conflicts in Syria, Turkey and Iran do not follow the boundaries cited by the Treaty of Lausanne, so they overflow into Iraqi Kurdistan. So-called Islamic State, which took over Mosul in 2014, did not stop until

16 This practice is not included in regional or local law. Information based on interviews conducted by the author in Iraqi Kurdistan (Duhok, Irbil, Suleimanija) in September 2017 and August 2018 with public administration employees from education, natural resources and security sectors

17 Regions defined by the article 140 of the Constitution of Iraq as being Arabized during Saddam Hussein rule in Iraq (Kirkuk, Ninewa, Salah ad-Din, Diyala). They were mainly inhabited by Assyrians, Yazidi, Turkomans, Kurds and Shabacs. Iraqi and Kurdish security forces were sharing control over those territories till the Daesh offensive in 2014 when most of the Iraqi Forces withdrew. 
the suburbs of Erbil - the capital of the Kurdistan Region - where under an American air raid, they had to halt their attack. Before that, the Daesh forces were strengthened on the territory of Syria. Similarly, the Kurdistan Workers' Party (PKK), which participated in internal conflict between Iraqi Kurds in the 1990s, shifted its forces to Iraqi Kurdistan from Turkey. Because of that, Ankara conducts military operations in the Kurdistan Region, including aerial bomb attacks. That military presence is unofficially accepted by the KRG because Turkey is a source of income. Teheran in not such an important donor as Turkey, so when it shells positions of the Democratic Party of Iranian Kurdistan (PDKI) located in Iraqi Kurdistan it receives strong condemnation from the KRG.

The factors described above correspond with the internal situation and impede RSSR. For example, the Daesh offensive from 2014 exacerbated the fiscal crisis of the KRG. Iraqi Kurds had taken many measures to limit the effects of the decline in revenues. One of them was the delay of investment projects and their value. The total volume of investments by the private sector in KRG was worth more almost 12.5 billion dollars in 2013. In 2015, those investments decreased to 796.2 million dollars (Board of investment 2015).

The second was to freeze the payment of government employees. This caused a series of protests and long-lasting social dissatisfaction. At the same time, Iraqi Kurdistan incurred debt with private and foreign companies and banks, and took out external loans. The effects of reducing investment in infrastructure are now noticeable through the stagnation of private sector and retention of some private investment. From 2010 to 2013, annual KRG investment spending rose at a compound annualised growth rate of $28 \%$ per annum to reach IQD 3.8 trillion (\$3.1 billion) (World Bank Group 2016, p. 20). Due to Daesh aggression in 2014, humanitarian and fiscal crisis work on most infrastructure projects was suspended (DeWeaver 2015, p. 8). Overdue payments to companies and contractors reduced trust in the KRG and discouraged foreign and local investments. Daesh exerted enormous pressure on the KRG by causing an influx of around 1,800,000 internally displaced persons, and forcing it to increase spending on the security sector. Funds were flown to satisfy immediate needs for securing the areas from where Iraqi Army withdrew. No funds were available for the RSSR and development. It 
also forced Peshmerga to focus on counter terrorism, which should be the task of the Ministry of Interior's forces ${ }^{18}$.

Before placing units 70' and $80^{\prime}$ ' under the MoPA, it is important to be assured about the forces' personal and material assets condition. Thus, one of the priorities for the RSSR should be introduction of electronic payment and a biometric census to prepare an appropriate budget and eliminate double dippers. It cannot be done without cooperation with the Ministry of Finance. It may cause the reluctance of some political leaders who are afraid that similar changes may occur in their ministries and as a consequence, deprive them of power.

Another barrier is the structure, as many officers are nominated by political parties. Commanders are often members and active activists of the political parties. They usually lack military experience and education. The reformed Peshmerga recruitment process would be conducted according to appropriate substantive rather than political merits. Abolition of the patronage institution is perceived as a threat by people who have received their positions through their family-clan-political connections. To prevent losing their status, they will execute their powers to ward off RSSR. Patronage and clientelism are so common that some of them cannot imagine another attitude and do not consider these issues as negative things.

\section{Conclusions}

This paper draws attention to the historical context which could explain the interests and aspirations of the local leaders. That is vital for conducting successful Regional Security Sector Reform. In the case of Iraqi Kurdistan, the impediments revolve around lack of recognition by the international community. This was a direct reason for the lack of efficient administration and the inadequate local government and society relationship and lack of economic development.

18 Verified in interviews with the representatives of Ministry of Peshmerga conducted in Iraqi Kurdistan in 2018. 
That combination pushed Iraqi Kurds into rentierism. Getting out of this is now impossible without international support.

he perception of insecurity in the region impedes investment in development of the security sector. Politicians who decide on the allocation of expenditures make attempts to increase the potential of forces controlled by political parties - units 70 ' and 80 .' Therefore, control of a military force is a more important attribute of political power in Iraq than of the support of its citizens. Some political leaders are also afraid that the loss of political control over security sub-sectors could cause loss of the political raison d'être. Possession of security apparatus allows the political party to survive despite the lack of public support.

\section{References}

Adwan, C. A. Corruption Terminology in the Arabic Language (pamphlet), [online] Available from http://siteresources.worldbank.org/INTMNAREGTOPGOVERNANCE/Reso urces/CharlespieceonTerminology.pdf. [Accessed 30 Aug 2018].

Barnett, M. and Zürcher, C., 2009. The peacebuilder's contract: How external statebuilding reinforces weak statehood. In The dilemmas of statebuilding. Routledge.

Beblawi, H., and Luciani, G., 1987. The Rentier State. London: Croom Helm.

Blanchard, M. and Katzman, K., 2009. Iraq: Oil-For-Food Program, Illicit Trade, and Investigations, CRS Report RL30472.

Chapman, D. P., 2009. Security Forces of the Kurdistan Regional Government, U.S. Army War College, Carlisle Barracks, PA 17013-5050.

David, P., 2007. Path Dependence: A Foundational Concept for Historical Social Science, Cliometrica, No. 1 (2).

DeWeaver, M., 2015. Kurdistan's Great Recession: From Boom to Bust in the Rentier Economy, Institute of Regional and International Studies at American University of Iraq, Sulaimani.

Fliervoet, F., 2018. Fighting for Kurdistan? Assessing the nature and functions of the Peshmerga in Iraq. CRU Report.

Helfont, S., 2017. Getting Peshmerga Reform Right: Helping the Iraqi Kurds to Help Themselves in Post-ISIS Iraq. A joint report by the Foreign Policy Research Institute (Philadelphia) and the Institute of Regional and International Studies at American University of Iraq, Sulaimani.

Heshmati, A., 2018. The Role of Natural Resources in Kurdistan Regional Government's Economic Development. UKH Journal of Social Sciences, 2 (1).

Kamiński, C. I., 2016. Kwalifikacja prawna operacji al-Anfal. Ekspertyza prawna, Warsaw. 
Karl, T. L., 1997. The Paradox of Plenty: Oil Booms and Petro-States. University of California Press, Ltd, London.

Kurpiewska-Korbut, R., 2014. Społeczność międzynarodowa wobec Kurdów irackich. Societas, Cracow.

KRG, Board of Investment, Department of Information and Studies, 'List of Licensed Projects', 1 August 2006-30 September 2015.

Leezenberg, M., 2000. Humanitarian aid in Iraqi Kurdistan, Cahiers d'études sur la Méditerranée orientale et le monde turco-iranien. Fondation nationale des science politiques, Centre d'études et de recherches internationales.

Mills, R., 2016. Under the Mountains: Kurdish Oil and Regional Politics. OIES paper: WPM 63 The Oxford Institute for Energy Studies.

Noori, N. N., 2016. The Failure of Economic Reform in the Kurdistan Region of Iraq (19212015): The Vicious Circle of Uncivic Traditions, Resource Curse, and Centralization. British Journal of Middle Eastern Studies, September.

North, D. C., 1994. Institutional Change: a Framework of Analysis. Economic History 9412001, University Library of Munich, Germany.

OECD DAC, 2007. Handbook on Security System Reform: Supporting Security and Justice. OECD Publishing, Paris.

Paris, R., 2004. At War's End: Building Peace after Civil Conflict. Cambridge University Press, Cambridge.

Ross, M. L., 2012. The Oil Curse: How Petroleum Wealth Shapes the Development of Nations. Princeton University Press, Princeton, NJ.

Rutledge, E., 2014. The Rentier State/Resource Curse narrative and the state of the Arabian Gulf. MPRA Paper No. 59501.

Sedra, M., 2010. Introduction: The Future Of Security Sector Reform. In Sedra M. (ed.) The Future Of Security Sector Reform. The Centre for International Governance Innovation, Waterloo, Ontario.

Smith, C., 2018. Independent Without Independence: The Iraqi Kurdish Peshmerga in International Law. Harvard International Law Journal 59, 245.

Stansfield, G. R. V., 2003. Iraqi Kurdistan Political development and emergent democracy. Routledge, London and New York.

World Bank Group, 2015. The Kurdistan Region of Iraq: Assessing the Economic and Social Impact of the Syrian Conflict and ISIS. [online] Available from: https:// openknowledge.worldbank.org/handle/10986/21637 [Accessed 30 Aug 2018].

World Bank Group., 2016. Kurdistan Region of Iraq: Reforming the Economy for Shared Prosperity and Protecting the Vulnerable. [online] Available from: http://documents. worldbank.org/curated/en/672671468196766598/pdf/106132-v2-main-reportP159972-PUBLIC-KRG-Economic-Reform-Roadmappost-Decision-Review-05-3016.pdf [Accessed 30 Aug 2018]. 